\title{
Ploidy stability in embryogenic cultures and regenerated plantlets of tamarillo
}

\author{
Lara Currais · João Loureiro • Conceição Santos • \\ Jorge M. Canhoto
}

Received: 19 November 2012/ Accepted: 23 February 2013/Published online: 2 March 2013

(C) Springer Science+Business Media Dordrecht 2013

\begin{abstract}
Ploidy levels of short-term (1 and 2 years) and long-term ( 7 and 10 years) embryogenic cultures as well as of regenerated plantlets of tamarillo were analyzed by flow cytometry and chromosome counts. Embryogenic cultures were induced from expanding leaves cultured in the presence of Picloram or 2,4-dichlorophenoxyacetic acid (2,4-D) and monthly subcultured on the same media. Embryo development and plantlets were obtained following subculture of the embryogenic tissue in auxin free medium containing gibberellic acid $\left(\mathrm{GA}_{3}\right)$. Seedlings and rooted shoots from axillary shoot proliferation were used as controls. The results showed that in long-term embryogenic cultures the ability to develop somatic embryos and plantlets was reduced. Embryogenic tissues maintained for 10 years were mostly aneuploids of the tetraploid $(2 \mathrm{n}=4 x=48)$ level whereas those kept in culture for 7 years or less were also mostly aneuploids but of the diploid $(2 n=2 x=24)$ level. The results obtained by flow cytometry were, in general, consistent with those obtained by chromosome counts. The chromosome alteration observed in the embryogenic tissues was already present after 1 year of culture and increased with culture age, hence impairing the maintenance of these tissues for long periods without affecting chromosome stability of the regenerated plantlets. However, the occurrence of
\end{abstract}

L. Currais · J. Loureiro · J. M. Canhoto $(\square)$

Laboratory of Plant Biotechnology, Department of Life

Sciences, CFE, Centre for Functional Ecology,

University of Coimbra, Calçada Martim de Freitas, Apartado,

P.O. Box 3046, 3001-401 Coimbra, Portugal

e-mail: jorgecan@ci.uc.pt

C. Santos

Department of Biology, CESAM, Centre for Environmental and Marine Studies, University of Aveiro, Campus Universitário de Santiago, 3810-193 Aveiro, Portugal triploids and tetraploids as well as aneuploids can be useful for breeding purposes. A value around $23 \mathrm{pg} / 2 \mathrm{C}$ was found for the genome size of tamarillo largely exceeding the value previously published $(15.50 \mathrm{pg} / 2 \mathrm{C})$.

Keywords Cyphomandra betacea .

Aneuploids · Mixoploids · Nuclear DNA content .

Somatic embryogenesis

$\begin{array}{ll}\text { Abbreviations } \\ \text { 2,4-D } & \text { 2,4-Dichlorophenoxyacetic acid } \\ \text { DAPI } & 4^{\prime} \text {,6-Diamidino-2-phenylindole } \\ \text { CV } & \text { Coefficient of variation } \\ \text { DI } & \text { DNA index } \\ \text { FCM } & \text { Flow cytometry } \\ \text { FL } & \text { Fluorescence integral } \\ \text { FS } & \text { Forward scatter } \\ \text { GA } & \text { Gibberellic acid } \\ \text { PI } & \text { Propidium iodide } \\ \text { SS } & \text { Side scatter }\end{array}$

\section{Introduction}

Cyphomandra betacea (Cav.) Sendt. (syn. Solanum betaceum), commonly known as tamarillo (Solanaceae family), is a fruit tree crop (Bois 1927; Correia and Canhoto 2012) native to the Andean regions of South America (Bois 1927; Fouque 1973). Over the years its economic exploitation has increased due to a renewed interest in the consumption of exotic fruits in some markets (Correia and Canhoto 2012). Tamarillo fruits are rich in vitamins $\mathrm{C}$ and $\mathrm{E}$ as well as in provitamin A (McCane and Widdowson 1992). High levels of potassium and iron (McCane and Widdowson 1992), 
anthocyanins (Hurtado et al. 2009) and other phenolics showing antioxidant properties have also been found (Kou et al. 2008).

Tamarillo has a diploid $(2 \mathrm{n}=2 x=24)$ set of chromosomes. However, spontaneous triploids, tetraploids and even aneuploids, have been reported (Standring et al. 1990; Pringle and Murray 1992). The nuclear DNA content $(2 \mathrm{C}=15.50 \mathrm{pg})$ was first assessed by Pringle and Murray (1991) using flow cytometry.

C. betacea can be propagated by seeds or through conventional macropropagation techniques such as grafting or cuttings (Slack 1976; Correia and Canhoto 2012). In vitro protocols have also been applied, including axillary shoot proliferation (Obando and Jordan 2001), organogenesis (Atkinson and Gardner 1993) and somatic embryogenesis (Guimarães et al. 1988; Lopes et al. 2000; Canhoto et al. 2005; Correia et al. 2011, 2012). Somatic embryogenesis has proved to be particularly interesting since high rates of somatic embryo induction and plant conversion can be achieved (Correia et al. 2012) both from juvenile and adult selected trees (Correia and Canhoto 2012).

In tamarillo, somatic embryos are formed in a common two step process (von Arnold 2008; Rose et al. 2010; Yang and Zhang 2010). Thus, embryogenic tissues formed in young leaves cultured on media containing the auxin 2,4dichlorophenoxyacetic acid (2,4-D) or Picloram develop into somatic embryos when the embryogenic tissues are transferred to an auxin free medium (Correia et al. 2012). On these conditions, the proliferating proembryogenic masses formed in the presence of the auxin initiate an organized pattern of development following the classical globular, heart-shaped, torpedo and cotyledonary stages of embryogenesis.

Previous reports have shown that tamarillo embryogenic tissues can be maintained in vitro for several years on media containing the auxins Picloram or 2,4-D without losing the ability to originate somatic embryos (Guimarães et al. 1996; Canhoto et al. 2005). This kind of embryogenic system is very useful for cloning particularly among trees which, due to their long life cycles, can only be evaluated in field assays several years after plantation. During this period, embryogenic tissues must keep both their ability to develop into embryos and plantlets and the potential to originate true-to-type plants to assure the cloning of interesting genotypes. Examples of long-term embryogenic cultures from which plantlets were obtained without any evidence of variations have been reported (Motoike et al. 2001; Loureiro et al. 2005; Lopes et al. 2006). However, works claiming the regeneration of plants showing genetic variability as a consequence of prolonged cultures are also common (von Aderkas et al. 2003; von Arnold 2008). Chromosome alteration in cultures is usually harmful but, in some cases, plants with abnormal chromosome numbers can be useful for breeding purposes (Koornneef et al. 1989; Kadota and Niimi 2002; Bairu et al. 2011).

Flow cytometry (FCM) is a powerful and reliable technique which has been used for screening the DNA content of a large number of embryogenic tissues and in vitro propagated plants (Pinto et al. 2004; Loureiro et al. 2005; Lattoo et al. 2006; Marum et al. 2009; Ochatt et al. 2011). Complemented with more traditional techniques of chromosome counting (e.g. Feulgen technique) it may give important insights about the chromosome stability of plant tissue cultures.

Over the last years we have been trying to characterize the processes of somatic embryogenesis induction, somatic embryo development and conversion in tamarillo (Correia and Canhoto 2012). The main goal of this study was to determine whether long-term embryogenic cultures of tamarillo maintain their potential to develop into somatic embryos and to assess the effects of these long term cultures on chromosome stability of embryogenic tissues and regenerated plantlets. This type of analysis is relevant to determine which strategy must be pursued in order to cope with somatic embryogenesis in tamarillo breeding programs.

\section{Materials and methods}

\section{Plant material}

Seeds were collected from mature fruits of selected diploid plants growing at the Botanic Garden of the University of Coimbra, sterilized in a solution of calcium hypochlorite (7\% w/v) for 15 to $20 \mathrm{~min}$, and rinsed three times with sterilized distilled water. Whole mature zygotic embryos were isolated and cultured in test tubes containing MS medium (Murashige and Skoog 1962) supplemented with $0.087 \mathrm{M}$ sucrose and $0.6 \%$ (w/v) agar (Panreac, Spain). The $\mathrm{pH}$ was adjusted to 5.7 prior to autoclaving at $121{ }^{\circ} \mathrm{C}$ for $20 \mathrm{~min}$. Cultures were maintained in a growth chamber at $25{ }^{\circ} \mathrm{C}$ under a $16 \mathrm{~h}$ daily illumination regime of $15-20 \mu \mathrm{mol} \mathrm{m}{ }^{-2} \mathrm{~s}^{-1}$ of photosynthetically active radiation provided by cool-white fluorescent lamps. The most apical expanding leaves were cut from 3 to $4 \mathrm{~cm}$ plantlets and used for the somatic embryogenesis induction assays.

Somatic embryogenesis induction

Somatic embryogenesis induction followed the protocols of Canhoto et al. (2005) and Correia et al. (2011). Briefly, wounded leaves were placed abaxial side down on the induction medium (MS basal medium supplemented with $20 \mu \mathrm{M}$ Picloram and $0.26 \mathrm{M}$ sucrose, $\mathrm{P}$ medium). Cultures were incubated at $25^{\circ} \mathrm{C}$, in the dark, until embryogenic tissue formation (12 weeks, approximately). After that, 
embryogenic tissues formed by clumps of proembryogenic masses were isolated from non-embryogenic calli and subcultured at 4-week intervals on the same conditions.

Somatic embryo development and conversion into plantlets

To promote somatic embryo development and further conversion into plantlets portions of the embryogenic tissues were transferred to MS solidified medium supplemented with $0.087 \mathrm{M}$ sucrose and $0.28 \mu \mathrm{M}$ gibberellic acid $\left(\mathrm{GA}_{3}\right)$. Afterwards, cultures were maintained at $25{ }^{\circ} \mathrm{C}$ under a $16 \mathrm{~h} /$ $8 \mathrm{~h}$ photoperiod and a light intensity of $15-20 \mu \mathrm{mol} \mathrm{m}^{-2} \mathrm{~s}^{-1}$ of photosynthetically active radiation for 4 weeks. Further plantlet development and acclimatization was conducted according to Correia et al. (2011).

Short and long-term cultures

Embryogenic tissues were maintained in culture for short (1-2 years) and long periods (7-10 years). Since $2,4-D$ has also proved to be effective in the induction and maintenance of embryogenic tissues, long-term embryogenic material induced and maintained for 7-10 years in a medium supplemented with $9 \mu \mathrm{M} 2,4-\mathrm{D}$ and $0.26 \mathrm{M}$ sucrose (D medium) in the same conditions as described above was also evaluated. Thus, the level of ploidy was analysed in embryogenic tissues maintained for 1, 2, 7 and 10 years in $\mathrm{P}$ medium (P1, P2, P7 and P10 cultures, respectively) and for 7 and 10 years in D medium (D7 and D10 cultures, respectively). Seedlings growing in MS basal medium and axillary shoots proliferating in the same conditions were used as controls. Five randomly selected portions of embryogenic tissues growing in the presence of 2,4-D or Picloram for different periods of time were used for FCM analysis. Whenever possible somatic embryo derived plantlets were obtained from these embryogenic samples. The set of an analysed embryogenic tissue and the respective plantlets, when applicable, was named "series". A total of 30 series was analysed corresponding to 6 ( $\mathrm{P}$ and $\mathrm{D}$ media) embryogenic cultures $\times 5$ representative samples.

Flow cytometry analysis

For FCM analysis of the embryogenic tissues and plantlets of somatic embryo origin the protocol of Galbraith et al. (1983) was followed. In brief, nuclear suspensions were obtained by chopping either embryogenic or leaf tissue $(20 \mathrm{mg})$ with $20 \mathrm{mg}$ of leaf tissue from tamarillo seedlings of known ploidy (control diploid standard) and with $50 \mathrm{mg}$ of Pisum sativum cv. Ctirad (additional reference standard, $2 \mathrm{C}=9.09$ pg DNA; Doležel et al. 1992) in a Petri dish containing $1 \mathrm{ml}$ of Tris. $\mathrm{MgCl}_{2}$ buffer (Pfosser et al. 1995).
The sample was filtered through a $50 \mu \mathrm{m}$ nylon filter and $50 \mu \mathrm{g} \mathrm{ml}^{-1}$ of propidium iodide (PI, Fluka) and $50 \mu \mathrm{g} \mathrm{ml}^{-1}$ of RNase (Sigma) were added. After incubation in ice for 5 min, samples were analysed in a Beckman-Coulter EpicsXL (Coulter Electronics, Hialeah, Florida, USA) flow cytometer. Prior to analysis, the instrument was checked for linearity with fluorescent beads (Beckman Coulter).

Data were collected in the form of four graphics: forward scatter (FS) versus side scatter (SS) cytogram, both in logarithmic (log) scale; fluorescence integral (FL) histogram; FL versus time cytogram; and FL pulse integral versus FL pulse height cytogram. In the last cytogram an "interest zone" was defined to discriminate doublets, partial nuclei, nuclei with associated cytoplasm and other debris (Brown et al. 1991). Approximately 10,000 nuclei were analysed per sample.

Usually, the use of one internal reference standard is sufficient per sample. However, when the occurrence of aneuploidy is expected, to improve the sensitivity of the assay it is suggested to use a second reference point (usually a plant of the same species with known chromosome number) (Vindeløv et al. 1983; Pfosser et al. 1995). Therefore, the ploidy level of each sample was given as a relative DNA index to Pisum sativum (DI, ratio between the sample $\mathrm{G}_{0} / \mathrm{G}_{1}$ peak mean and that of Pisum sativum) and for further confirmation of the ploidy level the ratio between the $G_{0} / G_{1}$ peak of our sample and that of the control diploid standard was used.

The holoploid genome size in pg $(\mathrm{C}$, complete genome size, sensu; Greilhuber et al. 2005) of this species was estimated using tamarillo plantlets from two trees (one producing yellow fruits and the other red fruits) by multiplying the DI by $9.09 \mathrm{pg}$ (the genome size of the reference standard, Pisum sativum). Conversion of mass values into base-pair numbers was done according to the factor $1 \mathrm{pg}=978 \mathrm{Mbp}$ (Doležel et al. 2003). Differences in genome size were assessed by a $t$ test (SigmaStat for Windows version 3.01 SPSS Inc., USA).

\section{Chromosome counts}

The number of chromosomes of embryogenic tissues and somatic-embryo derived plantlets was determined after treatment of embryogenic tissues and root tips with $0.05 \%$ (w/v) colchicine (Sigma) for $2-2.5 \mathrm{~h}$ at $25{ }^{\circ} \mathrm{C}$, in the dark. The treated samples were then fixed in $3: 1(\mathrm{v} / \mathrm{v})$ ethanol/ acetic acid for approximately $4 \mathrm{~h}$ at room temperature. The Feulgen technique (Darlington and La Cour 1976) was then applied. Accordingly, samples were hydrolyzed in $1 \mathrm{~N} \mathrm{HCl}$ at $60{ }^{\circ} \mathrm{C}$ for 6 min in a water bath, transferred to distilled water at room temperature for $5 \mathrm{~min}$, stained in Schiff reagent for $1-3 \mathrm{~h}$ in the dark and squashed in $45 \%$ acetic acid. Slides were observed using a Nikon Eclipse E400 
microscope and images registered with a Nikon Digital Sight DS-U1 camera using the Act-2U software.

As controls, the number of chromosomes was counted in roots (at least $1 \mathrm{~cm}$ length) of in vitro growing seedlings germinated in MS medium and in rooted shoots obtained from axillary shoot proliferation (Correia et al. 2011).

\section{Results}

Embryogenic cultures and plantlet formation

Embryogenic cultures of $C$. betacea were kept in $\mathrm{P}$ or D medium for up to 10 years and after the 1st, 2nd, 7th and 10th year (7 and 10 years in the case of D medium) were morphologically characterized and tested on their ability to develop into somatic embryos and plantlets (Table 1).

During the first 2 years (short-term cultures), embryogenic cultures were characterized by the proliferation of whitish proembryogenic masses (Fig. 1a) assembled in compact clusters of small, cytoplasm-rich cells. Embryogenic cultures maintained for longer periods (long-term cultures) in P or D medium showed some morphological and cytological changes namely a yellowish translucent aspect (Fig. 1b) and the presence of highly vacuolated cells. When embryogenic tissues from short-term embryogenic cultures were transferred to an auxin-free medium, but $\mathrm{GA}_{3}$-added, somatic embryos at different developmental stages were observed (Fig. 1c) from all the randomly chosen samples of those cultures. These embryos further developed into plantlets (Fig. 1d). More than $80 \%$ of the somatic embryo derived plantlets presented a normal phenotype (straight stem with fully expanded leaves, Fig. 1e). However, about $15 \%$ of the plantlets from 1-year-old and 2-years-old cultures displayed abnormal phenotypes characterized by a twisted stem with thick small leaves and reduced growth (Fig. 1f).

Attempts to promote somatic embryo development and plantlet formation from long-term cultures showed that they have lost most of its potential with only a few embryos arising from them. Moreover, the few plantlets obtained from these embryos showed quite aberrant phenotypes and potted plants could not be obtained.

\section{Flow cytometry analysis}

The DNA content of the embryogenic tissues and plantlets originated from cultures induced and maintained in P medium showed a wide range of variation among samples (Table 2). In the P series, only 3 out of 20 analysed embryogenic tissues were diploid (3, 4 and 5 of P1; DI $=2.54 \pm 0.024$; Table 2). In all the other cases aneuploid tissues were found. Illustrative histograms of a diploid plantlet and of the most common aneuploid situations are given in Fig. 2. Only one case of full duplication of the genome (tetraploidy) was detected in a plantlet regenerated from short-term cultures (DI $=5.09 ; \mathrm{P} 2$, series 5). However, the tissue that originated the tetraploid plantlet was found to be aneuploid (diploid with gain of a few chromosomes).

The occurrence of aneuploidy appeared to be age-related since diploid tissues and/or plantlets were only observed in short-term cultures. Different kinds of aneuploidy were detected (Table 2) such as: (1) diploids with gain of 1-3 chromosomes $(\mathrm{DI}=2.67 \pm 0.048$; in series 1 of $\mathrm{P} 1,1$ plantlet and 4 embryogenic tissues of $\mathrm{P} 2$ and in all series of P7); (2) triploids with loss of $2-3$ chromosomes (DI $=3.44$; in series 2 of P1); (3) tetraploids with loss of a 1-4 chromosomes (DI $=4.90$; in series 2 of P2) and (4) tetraploids with loss of 5-7 chromosomes (DI $=4.45 \pm 0.034$; in all P10 series, Fig. 3). With the exception of three series of P2 cultures, all the regenerated plantlets presented the same ploidy level of the tissues of origin. In the referred exceptions, the originated plantlets were diploid (in two cases) or tetraploid (one case) in spite of being originated from aneuploid tissues.

Aneuploidy was also the main condition observed in long-term embryogenic cultures maintained on 2,4-D (Table 3). Thus, in cultures kept for 7 years (D7), two series

Table 1 Morphological characterization of short and long-term embryogenic cultures and regenerated plantlets of Cyphomandra betacea

\begin{tabular}{|c|c|c|c|}
\hline Series number & Type of embryogenic tissue & Type of cells & Phenotype of plantlets \\
\hline \multicolumn{4}{|c|}{ Short-term cultures } \\
\hline $\mathrm{P} 1$ & Whitish proembryogenic masses & Compact clusters of small, cytoplasm-rich cells & Mostly normal $^{\mathrm{a}}$ \\
\hline $\mathrm{P} 2$ & Whitish proembryogenic masses & Compact clusters of small, cytoplasm-rich cells & Normal and abnormal ${ }^{\mathrm{b}}$ \\
\hline \multicolumn{4}{|c|}{ Long-term cultures } \\
\hline P7 and D7 & Yellowish translucent aspect & Vacuolated cells & Quite aberrant ${ }^{\mathrm{b}}$ \\
\hline P10 and D10 & Yellowish translucent aspect & Vacuolated cells & Quite aberrant ${ }^{\mathrm{b}}$ \\
\hline
\end{tabular}


Fig. 1 Development of somatic embryos and conversion into plantlets. a Embryogenic tissue from short-term cultures; b Embryogenic tissue from long-term cultures; c Somatic embryo development after 3 weeks on the development medium; d Somatic embryoderived plantlets after 8-10 weeks of development; e In vitro somatic embryoderived plantlet showing a normal phenotype; f Morphologically abnormal somatic embryo-derived plantlet. Bars $=0.5 \mathrm{~cm}$
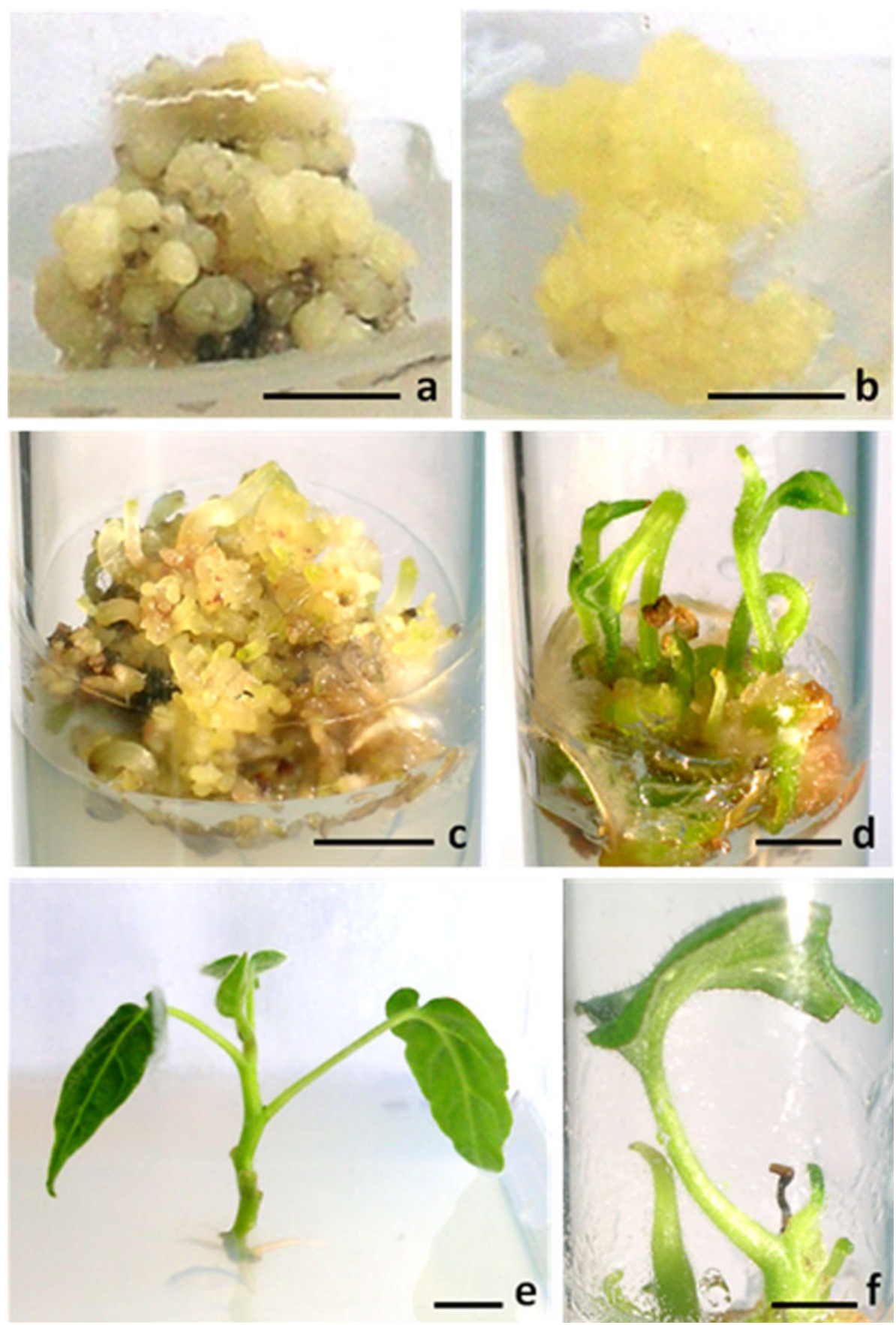

were diploid showing an increase of 1-3 chromosomes (DI $=2.68 \pm 0.035)$ whereas one D7 series was tetraploid (DI $=5.04$; series 4$)$ and two other were diploid (DI = $2.52 \pm 0.049$; series 3 and 5). For cultures kept for 10 years in 2,4-D (D10), tetraploidy was found in all series (Table 3) with loss of 5-7 chromosomes (DI $=4.56 \pm 0.037)$, a situation similar to that observed when the cultures were maintained in Picloram (Table 2) for the same period (DI $=4.51 \pm 0.066)$.

Mixoploidy was found in several samples, namely in two P (Table 2) and two D (Table 3) embryogenic cultures and in one plantlet from $\mathrm{P}$ cultures (Table 2). The simultaneous occurrence of mixoploidy in embryogenic tissue and in the corresponding plantlets was observed in P1 series (series 2).

The nuclear DNA content of $C$. betacea was estimated using diploid seedlings germinated in vitro. The mean coefficient of variation (CV) obtained for the DNA peaks was very low, 2.40 and $1.68 \%$, for the two sets of seedlings tested, one from a tree producing yellow fruits and other from a tree producing red fruits. Seedlings of both trees presented similar mean genome size estimations: 
Table 2 Analyses of the level of ploidy in short and long-term cultures maintained in Picloram

\begin{tabular}{|c|c|c|c|c|c|c|c|c|c|}
\hline \multirow{2}{*}{$\begin{array}{l}\text { Series } \\
\text { number }\end{array}$} & \multicolumn{4}{|c|}{ Embryogenic tissue } & \multicolumn{5}{|c|}{ Plantlets } \\
\hline & DI & $\mathrm{CV}(\%)$ & Interpretation & Mix. & DI & $\mathrm{CV}(\%)$ & Interpretation & Mix. & $\begin{array}{l}\text { No. of } \\
\text { chrom. }\end{array}$ \\
\hline \multicolumn{10}{|l|}{$P 1$} \\
\hline 1 & 2.67 & 4.23 & An. $-2 \mathrm{C}$ with chrom. gain & $\mathrm{n}$ & 2.64 & 2.86 & An. $-2 \mathrm{C}$ with chrom. gain & $\mathrm{n}$ & - \\
\hline 2 & 3.44 & 2.10 & An. $-3 \mathrm{C}$ with chrom. loss & $\mathrm{y}$ & 3.46 & 2.37 & An. $-3 \mathrm{C}$ with chrom. loss & $\mathrm{y}$ & - \\
\hline 3 & 2.54 & 2.57 & $2 \mathrm{C}$ & $\mathrm{y}$ & 2.55 & 1.82 & $2 \mathrm{C}$ & $\mathrm{n}$ & 24 \\
\hline 4 & 2.58 & 1.87 & $2 \mathrm{C}$ & $\mathrm{n}$ & 2.54 & 2.21 & $2 \mathrm{C}$ & $\mathrm{n}$ & 24 \\
\hline 5 & 2.51 & 2.46 & $2 \mathrm{C}$ & $\mathrm{n}$ & 2.52 & 2.05 & $2 \mathrm{C}$ & $\mathrm{n}$ & 24 \\
\hline \multicolumn{10}{|l|}{$P 2$} \\
\hline 1 & 2.65 & 2.51 & An. $-2 \mathrm{C}$ with chrom. gain & $\mathrm{n}$ & 2.65 & 2.62 & An. $-2 \mathrm{C}$ with chrom. gain & $\mathrm{n}$ & 44 \\
\hline 2 & 4.90 & 2.22 & An. $-4 \mathrm{C}$ with chrom. loss & $\mathrm{n}$ & 4.96 & 2.29 & An. - 4C with chrom. loss & $\mathrm{n}$ & 42 \\
\hline 3 & 2.66 & 2.88 & An. $-2 \mathrm{C}$ with chrom. gain & $\mathrm{n}$ & 2.45 & 2.18 & $2 \mathrm{C}$ & $\mathrm{n}$ & 24 \\
\hline 4 & 2.66 & 1.82 & An. $-2 \mathrm{C}$ with chrom. gain & $\mathrm{n}$ & 2.46 & 2.43 & $2 \mathrm{C}$ & $\mathrm{n}$ & - \\
\hline 5 & 2.67 & 2.60 & An. $-2 \mathrm{C}$ with chrom. gain & $\mathrm{n}$ & 5.09 & 2.44 & $4 \mathrm{C}$ & $\mathrm{n}$ & - \\
\hline \multicolumn{10}{|l|}{$P 7$} \\
\hline 1 & 2.82 & 2.00 & An. $-2 \mathrm{C}$ with chrom. gain & $\mathrm{n}$ & - & & - & - & - \\
\hline 2 & 2.69 & 3.20 & An. $-2 \mathrm{C}$ with chrom. gain & $\mathrm{n}$ & - & & - & - & - \\
\hline 3 & 2.66 & 2.86 & An. $-2 \mathrm{C}$ with chrom. gain & $\mathrm{n}$ & - & & - & - & - \\
\hline 4 & 2.65 & 2.30 & An. $-2 \mathrm{C}$ with chrom. gain & $\mathrm{n}$ & - & & - & - & - \\
\hline 5 & 2.66 & 1.56 & An. $-2 \mathrm{C}$ with chrom. gain & $\mathrm{n}$ & - & & - & - & - \\
\hline \multicolumn{10}{|l|}{ P10 } \\
\hline 1 & 4.49 & 1.78 & An. $-4 \mathrm{C}$ with chrom. loss & $\mathrm{n}$ & - & & - & - & - \\
\hline 2 & 4.41 & 1.46 & An. $-4 \mathrm{C}$ with chrom. loss & $\mathrm{n}$ & - & & - & - & - \\
\hline 3 & 4.46 & 1.48 & An. $-4 \mathrm{C}$ with chrom. loss & $\mathrm{n}$ & - & & - & - & - \\
\hline 4 & 4.43 & 1.61 & An. $-4 \mathrm{C}$ with chrom. loss & $\mathrm{n}$ & - & & - & - & - \\
\hline 5 & 4.48 & 1.84 & An. - 4C with chrom. loss & $\mathrm{n}$ & - & & - & - & - \\
\hline
\end{tabular}

$\mathrm{P}$ refers to the presence of Picloram in the induction medium and the number $(1,2,7$ or 10) refers to the culture age in years. DI stands for DNA index. $\mathrm{CV}$ of the $\mathrm{G}_{0} / \mathrm{G}_{1}$ peak of sample nuclei is also provided

An. aneuploid, $2 C$ diploid, $3 C$ triploid, $4 C$ tetraploid, chrom. chromosomes, Mix. mixoploid: the presence of two cell lines, one diploid or aneuploid, and one with the double amount of DNA (y, yes; n, no)

$23.31 \pm 0.566 \mathrm{pg} / 2 \mathrm{C}$ (approx. $11399 \mathrm{Mbp} ; \mathrm{CV}=2.4 \%$ ) for the tree producing the red fruits, and $23.53 \pm 0.117 \mathrm{pg} /$ $2 \mathrm{C}$ (approx. 11,506 Mbp; $\mathrm{CV}=0.5 \%$ ) for the tree producing yellow fruits. A $t$ test revealed that the observed differences in DNA content were not statistically significant $(P<0.05)$.

\section{Chromosome counts}

Chromosome counts were also used to assess the level of ploidy of the embryogenic tissues and plantlets. The results showed that this approach was much more successful with roots than with the embryogenic tissue, since the number of cells showing c-metaphases in this tissue was quite reduced. In spite of this, it was possible to record the chromosome number in both somatic embryo derived plantlets and embryogenic tissues of some of the P1 and P2 series (short-term cultures).
In somatic embryo derived plantlets in which the ploidy level was found to be $2 \mathrm{n}=2 x$ by FCM (Table 2), chromosome counts confirmed the results and the plantlets tested showed the expected 24 chromosomes (Table 2, Fig. 4a). Seedlings and rooted shoots obtained by axillary shoot proliferation displayed also the diploid set of chromosomes.

In general, the data of chromosome counts matched those of FCM. For instance, the tetraploid plant with chromosome loss of $\mathrm{P} 2$ series 2 presented 42 chromosomes, 6 lesser than the expected number for a tetraploid (Fig. 4b). The same was observed in embryogenic tissues in which the aneuploid status found for most of them by FCM was confirmed by chromosome counts (Table 2, Fig. 4c). However, some unexpected results were also detected: a plantlet (P2 series 1) considered aneuploid by FCM (2C with extra chromosomes), after chromosome counts showed to possess 44 chromosomes (4C with loss of 4 chromosomes). 
Fig. 2 Histograms of PI fluorescence (in relative units) obtained after simultaneous analysis of nuclei isolated from leaves of Pisum sativum cv. Ctirad ( $2 \mathrm{C}=9.09$ pg DNA), as internal reference standard (peak 1), C. betacea seedlings (control, peak 2) and from different embryogenic tissues: a P1 embryogenic tissue, series 4 (diploid, peak 2); b P7, series 1 (diploid with gain of chromosomes, peak 3); c P1, series 2 (triploid with loss of chromosomes, peak 3); d P10, series 4 (tetraploid with loss of chromosomes, peak 3)

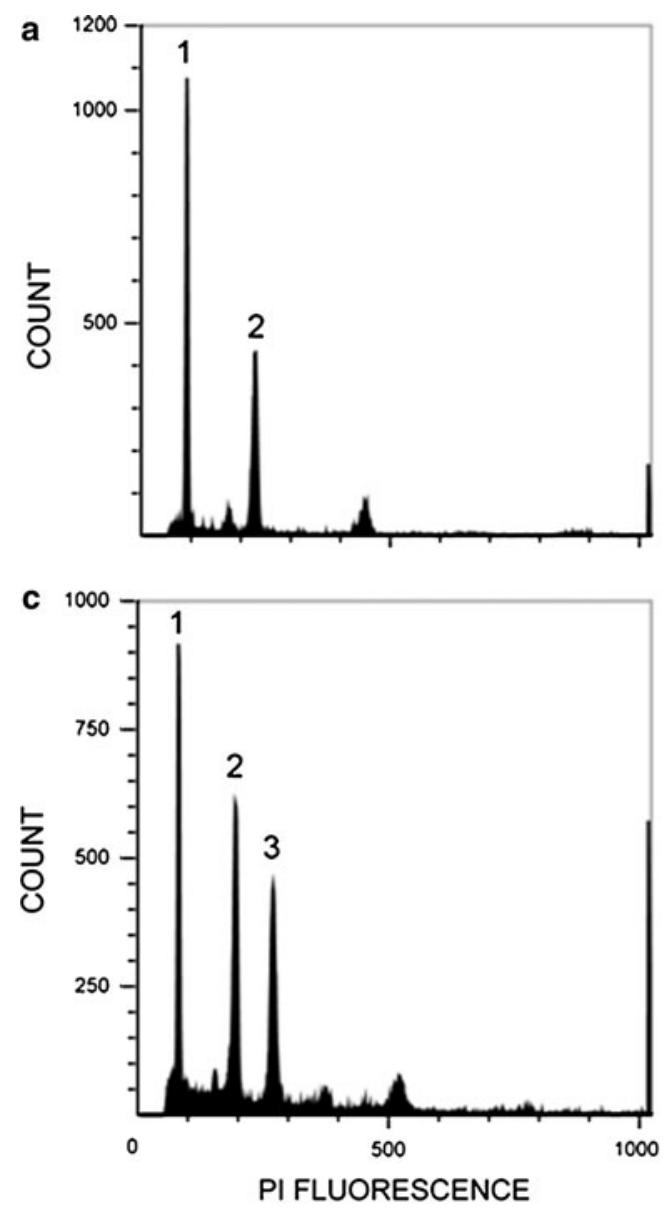

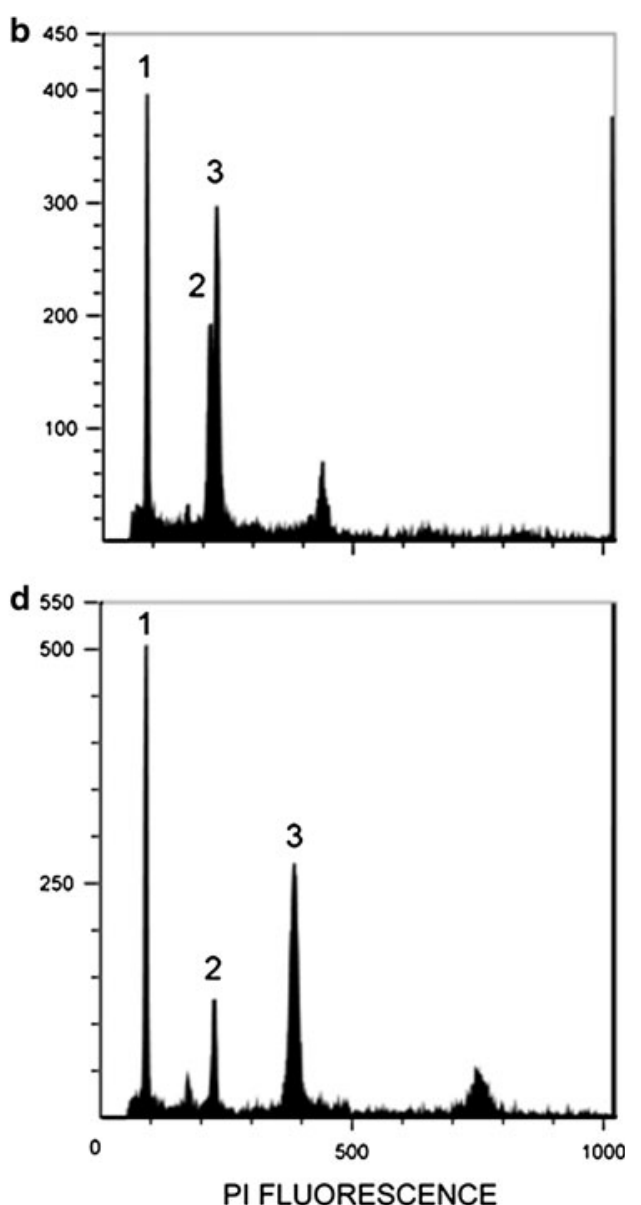

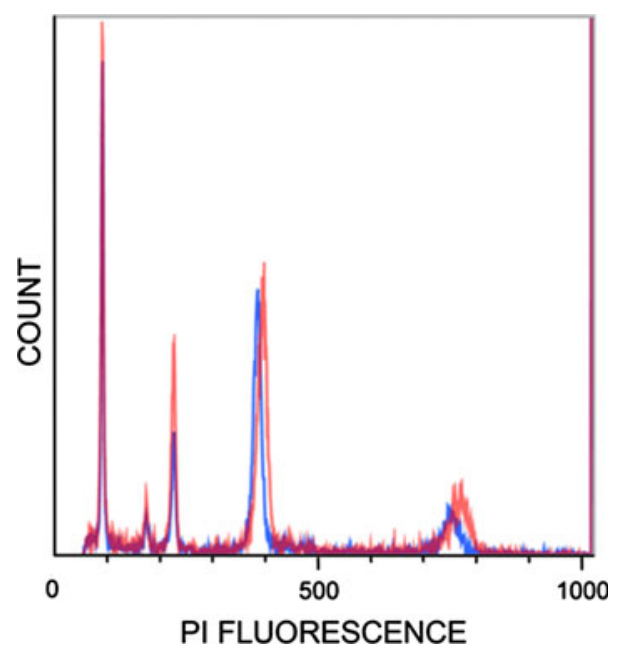

Fig. 3 Overlay of PI fluorescence histograms (in relative units) of embryogenic tissue from P10 (series 4, tetraploid with loss of chromosomes, blue line, DI $=4.43$ ) and D7 (series 4, tetraploid, red line, DI = 5.04). (Color figure online)

A detailed analysis of chromosome number in shortterm cultures kept on 2,4-D medium was neither carried out by FCM nor chromosome counts. However, chromosome counts in random analysed plantlets obtained from a 2-year-old embryogenic tissue indicated the presence of aneuploids (43, 45 and 46 chromosomes) and one tetraploid (Fig. 4d).

\section{Discussion}

The main objective of this work was to assess ploidy stability of embryogenic tissues of $C$. betacea maintained in culture for long periods. Both techniques used (FCM and chromosome counts) revealed the presence of abnormal sets of chromosomes indicating that embryogenic cultures of tamarillo are prone to chromosome alteration.

Our study revealed that 1 year of culture in the referred conditions was sufficient to induce abnormal chromosome numbers in some embryogenic cultures. With the extension of the culture period, the rates of genetic variation were much higher, with almost all series presenting modifications in chromosome number.

In short-term cultures, despite some ploidy changes in the embryogenic tissues (aneuploidy or mixoploidy), in three cases the regenerated plants were diploid. For series 3 of P1 the main diploid cell line prevailed over the 
Table 3 Analyses of the level of ploidy in long-term cultures maintained in 2,4-D

\begin{tabular}{lllll}
\hline Series number & DI & CV (\%) & Interpretation & Mix. \\
\hline D7 & & & & \\
1 & 2.71 & 1.76 & An. - 2C with chrom. gain & $\mathrm{n}$ \\
2 & 2.66 & 3.29 & An. - 2C with chrom. gain & $\mathrm{y}$ \\
3 & 2.55 & 1.82 & 2C & $\mathrm{y}$ \\
4 & 5.04 & 1.64 & $4 \mathrm{C}$ & $\mathrm{n}$ \\
5 & 2.48 & 1.85 & 2C & $\mathrm{n}$ \\
D10 & & & & \\
1 & 4.59 & 1.71 & An. - 4C with chrom. loss & $\mathrm{n}$ \\
2 & 4.59 & 1.61 & An. - 4C with chrom. loss & $\mathrm{n}$ \\
3 & 4.57 & 2.17 & An. - 4C with chrom. loss & $\mathrm{n}$ \\
4 & 4.56 & 1.67 & An. - 4C with chrom. loss & $\mathrm{n}$ \\
5 & 4.50 & 1.52 & An. - 4C with chrom. loss & $\mathrm{n}$ \\
\hline
\end{tabular}

$\mathrm{D}$ refers to the presence of 2,4-D in the induction medium and the number (7 or 10) refers to the culture age in years. DI stands for DNA index. $C V$ of the $G_{0} / G_{1}$ peak of sample nuclei is also provided

$A n$. aneuploid, $2 C$ diploid, $3 C$ triploid, $4 C$ tetraploid, chrom. chromosomes, Mix. mixoploid: the presence of two cell lines, one diploid or aneuploid, and one with the double amount of DNA (y, yes; n, no)

tetraploid one in the conversion into plantlets. For series 3 and 4 of $\mathrm{P} 2$, regeneration of diploid plants may be justified by the occurrence of mixture of diploid and aneuploid cells in the embryogenic tissue in which diploids might be undetected as they have the same fluorescence as the diploid seedlings used as control. In these tissues diploid cells may have a higher dividing capacity and stability, being able to develop into somatic embryos. Similar results were obtained in Dianthus callus cultures (Nontaswatsri and Fukai 2005) and in long-term cultures of Citrus sinensis (Hao and Deng 2002). According to the authors, plant regeneration in long-term cultures tend to select against cells showing abnormal sets of chromosomes, due to a greater stability of the normal diploid karyotype.

Although not common, the occurrence of mixoploidy in regenerated plants may indicate that some of the somatic embryos had a multicellular origin (the embryogenic cultures from which they developed were also mixoploid). The presence of somatic embryos of both unicellular and multicellular origin in the same system has been reported for several other species such as Cocos nucifera (Chan et al. 1998), Feijoa sellowiana (Canhoto and Cruz 1996), Hordeum vulgare (Nonohay et al. 1999) and Santalum album and S. spicatum (Rugkhla and Jones 1998). Also, the multicellular origin of somatic embryos seems to occur with a higher probability in indirect somatic embryogenesis systems, as is the case in tamarillo, than during direct embryo formation (see Gaj 2004).

In series 5 of $\mathrm{P} 2$, a similar situation to the one described above for series 3 and 4 of P2 may have occurred (a
Fig. 4 Karyological analysis using the Feulgen technique. a c-Metaphase showing the diploid set of chromosomes $(2 \mathrm{n}=2 x=24)$ from a P1, series 5, plantlet; b Cell with 42 c-metaphasic chromosomes (aneuploid) from a P2, series 2, plantlet; c c-Metaphase showing 26 chromosomes (aneuploid) from an embryogenic tissue of P2 cultures; d Cell showing a tetraploid set of chromosomes $(2 \mathrm{n}=4 x=48)$ from a plantlet regenerated from 2-years-old cultures in D medium.

Bars $=10 \mu \mathrm{m}$

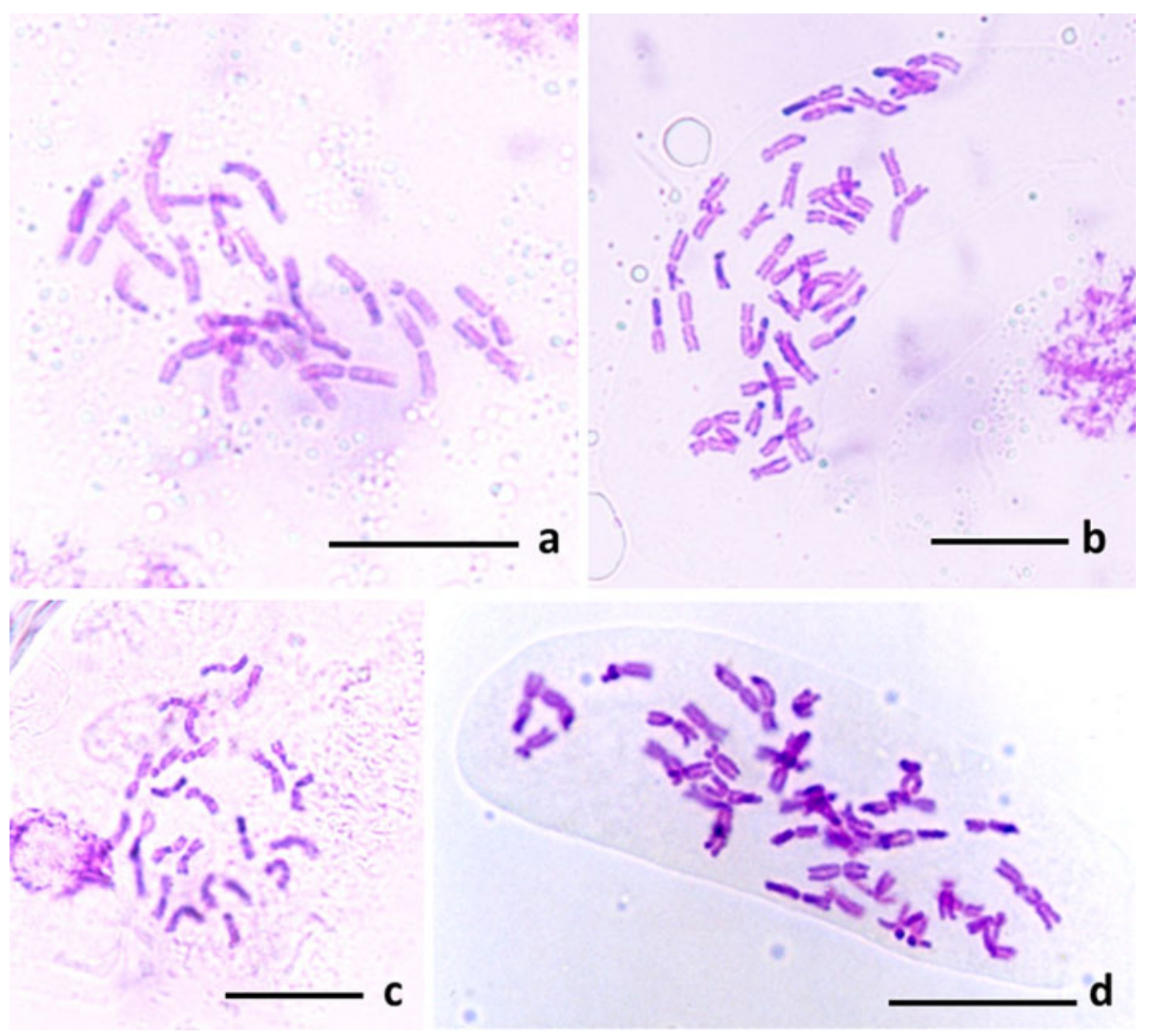


mixture of diploid and aneuploid cells in the embryogenic tissue with diploids undetected by FCM). However, the analysed regenerated plantlet was tetraploid. This may be justified with the occurrence of endoreduplication (Breuer and Sugimoto-Shirasu 2007) during culture. This explanation is supported by recent works reporting an association between endoreduplication and the differentiation of cells and organs (Lee et al. 2009; Bourdon et al. 2011). Moreover, endoreduplication seems to occur in response to some types of physiological stress (Lee et al. 2009), which can be the case of cultures maintained for several years in media containing auxins.

Beyond the increase of cytogenetic abnormalities, a reduction in embryogenic potential in all long-term cultures was also found. Similar results were recently obtained in Kalopanax septemlobus cultures (Park et al. 2011). Numerical and structural chromosome variations in longterm cultures disturb the physiological and genetic balance of proliferating cells causing a loss of the regeneration potential (Torrey 1967; Singh 1986). Indeed, the results of this study are consistent with those reported by many authors where an association between chromosome alteration and a reduction in the regeneration ability of the tissue cultures has been observed (Navok 1980; Jha and Roy 1982; Henry et al. 1994; von Aderkas et al. 2003; Kumar and Mathur 2004). Furthermore, in our study, the increasing age of cultures was accompanied by abnormal morphologies of embryos and plantlets and by difficulties on the conversion of abnormal embryos, hence suggesting a relation between the loss of regeneration capability and morphological and cytogenetic abnormalities (Ochatt et al. 2011; Konieczny et al. 2012).

One of the regenerated plantlets of P2 cultures was diploid, however its phenotype was considered to be abnormal (data not shown). This suggests that the morphology of the in vitro plants is dependent not only on the ploidy level but also on other factors such as epigenetics processes or external conditions like the culture media composition. A similar observation was made in Pinus pinaster, where normal and abnormal phenotypes of embryos and emblings did not present differences at the whole genome level (Marum et al. 2009). Moreover, a recent work (Linacero et al. 2011) suggested the existence of a common mechanism connecting both genetic and epigenetic variations promoted by in vitro conditions in cultures of rye.

The composition of the culture medium is a factor that may also influence the behaviour of in vitro cultures. Previous works have already shown that the presence of auxins in the culture medium, associated with extended maintenance periods, may lead to genetic variation (von Arnold et al. 2002; Gaj 2004). For example, sweet potato callus grown on 2,4-D for long periods showed genetic variations (Padmanabhan et al. 2001). Even in recent cultures (4 months) changes in DNA content can appear as found in Coffea arabica (Clarindo et al. 2012). However, contradictory results have been also reported showing that the presence of the 2,4-D did not affect the ploidy during somatic embryogenesis induction (Lema-Rumińska 2011). In tamarillo the role of the type of auxin seems not to be a crucial factor on embryogenic tissue behaviour since no particular differences between the DNA content of longterm cultures maintained in 2,4-D or Picloram were found.

Our results showed that, in all but one case, the results obtained by chromosome counts and FCM were in accordance. The exception was series 1 of $\mathrm{P} 2$ cultures in which FCM analysis revealed an aneuploid status for the diploid level (diploid with a few extra chromosomes) whereas chromosome counts indicated a tetraploid with less 4 chromosomes. A possible explanation for this discrepancy may be the time lapse between FCM and chromosome counts analyses (approx. 6 months), that may have originated extra variations in chromosome number.

FCM allowed the estimation of the genome size of tamarillo. No significant differences were detected between trees producing red and yellow fruits, but a large difference exists between these values and the one available in the literature $(2 \mathrm{C}=15.50 \mathrm{pg} / \mathrm{DNA}$; Pringle and Murray 1991). Even though both estimations were performed by FCM, the differences can be attributed not only to the use of a different fluorochrome (PI in the present study and 4',6-diamidino-2phenylindole (DAPI) in the previous work), but especially to a different reference standard: Pisum sativum cv. Ctirad in our work and Pigeon erythrocytes by Pringle and Murray (1991). The use of DAPI has long been considered inappropriate for genome size estimations due to its specificity to A-T bases (Greilhuber et al. 2007), leading to biased estimations of genome size. However, this effect by itself cannot account for the huge differences detected $(7.8 \mathrm{pg})$. The use of Pigeon erythrocytes seems to be the main cause of such differences, as the authors assumed it to contain 2 pg of DNA (according to Rees and Jones 1972), a value that is much lower than that available in the Animal Genome Size Database (Gregory 2012) for Columba livia (Rock Pigeon, 2C ranging from 2.92 to $3.18 \mathrm{pg} / \mathrm{DNA}$ ). Whether any of these values is considered as standard, the $2 \mathrm{C}$ genome size estimation by Pringle and Murray (1991) will be within 22.63-24.65 pg/DNA, which is in accordance with the estimation presented in our results.

In conclusion, this work revealed that long-term embryogenic cultures of tamarillo are prone to display chromosome variation, even after 1 year in culture, and should be regularly monitored through the use of FCM and/or chromosome counts. Such variation, associated with a decrease on regeneration capacity with culture age, implies difficulties in clonal propagation through somatic embryogenesis in long-term 
cultures of this species. In this context, alternative ways of preserving embryogenic tissues such as cryopreservation must be considered. However, such chromosomal alteration and other causes of genetic variation may also be useful as demonstrated by Bairu et al. (2011). In fact, aneuploid lines are often used in genetic research, whereas triploid and tetraploid plants are interesting for breeding purposes.

Acknowledgments This work was supported by the Portuguese Foundation for Science and Technology (FCT).

\section{References}

Atkinson RG, Gardner RC (1993) Regeneration of transgenic tamarillo plants. Plant Cell Rep 12:347-351. doi:10.1007/BF00237433

Bairu MW, Aremu AO, Staden JV (2011) Somaclonal variation in plants: causes and detection methods. Plant Growth Regul 63: 147-173. doi:10.1007/s10725-010-9554-x

Bois D (1927) Les Plantes Alimentaires chez tous les peuples et à travers les âges. In: Lechevalier P (ed) Phanérogames légumières, vol. I, Paris, pp 365-366

Bourdon M, Coriton O, Pirello J, Cheniclet C, Brown SC, Poujol C, Chevalier C, Renaudin J-P, Frangne N (2011) In planta quantification of endoreduplication using fluorescent in situ hybridization (FISH). Plant J 66:1089-1099. doi:10.1111/j.1365313X.2011.04568.x

Breuer C, Sugimoto-Shirasu K (2007) Endoreduplication and cell-size control in plants. In: Roberts K (ed) Handbook of plant science, vol 1. Wiley, England, pp 346-352

Brown S, Bergounioux C, Tallet S, Marie D (1991) Flow cytometry of nuclei for ploidy and cell cycle analysis. In: Negrutiu I, GhartiChherti G (eds) A laboratory guide for cellular and molecular plant biology. Bikhauser, Basel, pp 326-345

Canhoto JM, Cruz GS (1996) Histodifferentiation of somatic embryos in cotyledons of pineapple guava (Feijoa sellowiana Berg.). Protoplasma 191:34-45. doi:10.1007/BF01280823

Canhoto JM, Lopes ML, Cruz GS (2005) Protocol for somatic embryogenesis: tamarillo (Cyphomandra betacea (Cav.) Sendt.). In: Jain SM, Gupta PK (eds) Protocol for somatic embryogenesis in woody plants. Springer, Dordrecht, pp 379-389

Chan JL, Saenz L, Talavera C, Hornung R, Robert M, Oropeza C (1998) Regeneration of coconut (Cocos nucifera L.) from plumule explants through somatic embryogenesis. Plant Cell Rep 17: 515-521. doi:10.1007/s002990050434

Clarindo WR, Carvalho CR, Mendonça MAC (2012) Ploidy instability in long-term in vitro cultures of Coffea arabica L. monitored by flow cytometry. Plant Growth Regul 68:533-538. doi:10.1007/s10725012-9740-0

Correia S, Canhoto JM (2012) Biotechnology of tamarillo (Cyphomandra betacea): from in vitro cloning to genetic transformation. Sci Hort 148:161-168. doi:10.1016/j.scienta.2012.09.037

Correia S, Lopes ML, Canhoto JM (2011) Somatic embryogenesis induction system for cloning an adult Cyphomandra betacea (Cav.) Sendt. (tamarillo). Trees 25:1009-1020. doi:10.1007/s00468011-0575-5

Correia S, Cunha AE, Salgueiro L, Canhoto JM (2012) Somatic embryogenesis in tamarillo (Cyphomandra betacea): approaches to increase efficiency of embryo formation and plant development. Plant Cell Tiss Org Cult 109:143-152. doi:10.1007/s11240011-0082-9

Darlington CD, La Cour LF (1976) The handling of chromosomes, 6th edn. George Allen \& Unwin Ltd, London, pp 125-126
Doležel J, Sgorbati S, Lucretti S (1992) Comparison of three DNA fluorochromes for flow cytometric estimation of nuclear DNA content in plants. Physiol Plant 85:625-631. doi:10.1111/j.13993054.1992.tb04764.x

Doležel J, Bartos J, Voglmayr H, Greilhuber J (2003) Nuclear DNA content and genome size of trout and human. Cytom Part A 51A:127-128. doi:10.1002/cyto.a.10013

Fouque A (1973) Solanacées. Fruits 28:41-42

Gaj MD (2004) Factors influencing somatic embryogenesis induction and plant regeneration with particular reference to Arabidopsis thaliana (L.) Heynh. Plant Growth Regul 43:27-47. doi:10.1023/ B:GROW.0000038275.29262.fb

Galbraith DW, Harkins KR, Maddox JM, Ayres NM, Sharma DP, Firoozabady E (1983) Rapid flow cytometric analysis of the cellcycle in intact plant-tissues. Science 220:1049-1051. doi:10.1126/ science. 220.4601 .1049

Gregory TR (2012) Animal genome size database. http://www.genomesize.com. Accessed Oct 2012

Greilhuber J, Doležel J, Lysak MA, Bennett MD (2005) The origin, evolution and proposed stabilization of the terms "genome size" and "C-value" to describe nuclear DNA contents. Ann Bot 95: 255-260. doi:10.1093/aob/mci019

Greilhuber J, Temsch E, Loureiro J (2007) Nuclear DNA content measurement. In: Doležel J, Greilhuber J, Suda J (eds) Flow cytometry with plant cells. Wiley-Vch, Weinheim, pp 67-101

Guimarães ML, Cruz GS, Montezuma-de-Carvalho JM (1988) Somatic embryogenesis and plant regeneration in Cyphomandra betacea (Cav.) Sendt. Plant Cell Tiss Org Cult 15:161-167. doi: 10.1007/BF00035757

Guimarães ML, Tomé MC, Cruz GS (1996) Cyphomandra betacea (Cav.) Sendtn. (Tamarillo). In: Bajaj YPS (ed) Biotechnology in agriculture and forestry, vol 35, Trees IV. Springer, Berlin, pp 120-137

Hao YJ, Deng XX (2002) Occurrence of chromosomal variations and plant regeneration from long-term-cultured citrus callus. In Vitro Cell Dev Biol Plant 38:472-476. doi:10.1079/IVP2002317

Henry Y, Vain P, De Buyser J (1994) Genetic analysis of in vitro plant tissue culture responses and regeneration capacities. Euphytica 79:45-58. doi:10.1007/BF00023575

Hurtado NH, Morales AL, González-Miret ML, Escudero-Gilete ML, Heredia FJ (2009) Colour, pH stability and antioxidant activity of anthocyanin rutinosides isolated from tamarillo fruit (Solanum betaceum Cav.). Food Chem 117:88-93. doi:10.1016/j.foodchem. 2009.03.081

Jha TB, Roy SC (1982) Chromosomal behaviour in cultures of Vicia faba. Cytologia 47:465-470. doi:10.1508/cytologia.47.465

Kadota M, Niimi Y (2002) In vitro induction of tetraploid plants from a diploid Japanese pear cultivar (Pyrus pyrifolia N. cv. Hosui). Plant Cell Rep 21:282-286. doi:10.1007/s00299-002-0509-1

Konieczny R, Sliwinska E, Pilarska M, Tuleja M (2012) Morphohistological and flow cytometric analyses of somatic embryogenesis in Trifolium nigrescens Viv. Plant Cell Tiss Organ Cult 109: 131-141. doi:10.1007/s11240-011-0081-X

Koornneef M, van Diepen JAM, Hanhart CJ, Kieboom-de Waart AC, Martinelli L, Schoenmakers HCH, Wijbrandi J (1989) Chromosomal instability in cell- and tissue cultures of tomato haploids and diploids. Euphytica 43:179-186. doi:10.1007/BF00037911

Kou M, Yen J, Hong J, Wang C (2008) Cyphomandra betacea Sendt. Phenolics protect LDL from oxidation and PC12 cells from oxidative stress. LWT-Food. Sci Technol 42:458-463. doi: 10.1016/j.1wt.2008.09.010

Kumar PS, Mathur VL (2004) Chromosomal instability in callus culture of Pisum sativum. Plant Cell Tissue Organ Cult 78: 267-271. doi:10.1023/B:TICU.0000025669.11442.3e

Lattoo SK, Bamotra S, Dhar RS, Khan S, Dhar AK (2006) Rapid plant regeneration and analysis of genetic fidelity of in vitro derived 
plants of Chlorophytum arundinaceum Baker-an endangered medicinal herb. Plant Cell Rep 25:499-506. doi:10.1007/s00299005-0103-4

Lee HO, Davidson JM, Duronio RJ (2009) Endoreplication: polyploidy with purpose. Genes Dev 23:2461-2477. doi:10.1101/gad. 1829209

Lema-Rumińska J (2011) Flow cytometric analysis of somatic embryos, shoots, and calli of the cactus Copiapoa tenuissima Ritt. forma monstruosa. Plant Cell Tiss Org Cult 106:531-535. doi:10.1007/s11240-011-9941-7

Linacero R, Rueda J, Esquivel E, Bellido A, Domingo A, Vázquez AM (2011) Genetic and epigenetic relationship in rye, Secale cereale L., somaclonal variation within somatic embryo-derived plants. In Vitro Cell Dev Biol Plant 47:618-628. doi:10.1007/s11627011-9407-y

Lopes ML, Ferreira MR, Carloto JM, Cruz GS, Canhoto JM (2000) Somatic embryogenesis induction in Tamarillo (Cyphomandra betacea). In: Jain SM, Gupta PK, Newton RJ (eds) Somatic embryogenesis in woody plants, vol 6. Kluwer Academic Publishers, Dordrecht, pp 433-455

Lopes T, Pinto G, Loureiro J, Costa A, Santos C (2006) Determination of genetic stability in long-term somatic embryogenic cultures and derived plantlets of cork oak using microsatellite markers. Tree Physiol 26:1145-1152. doi:10.1093/treephys/26.9.1145

Loureiro J, Pinto G, Lopes T, Doležel J, Santos C (2005) Assessment of ploidy stability of the somatic embryogenesis process in Quercus suber L. using flow cytometry. Planta 221:815-822. doi:10.1007/s00425-005-1492-x

Marum L, Loureiro J, Rodriguez E, Santos C, Oliveira M, Miguel C (2009) Flow cytometric and morphological analyses of Pinus pinaster somatic embryogenesis. J Biotechnol 143:288-295. doi: 10.1016/j.jbiotec.2009.08.001

McCane J, Widdowson DA (1992) Fruit and Nut. Supl: the composition of foods, 5th edn. Holland, Unwin and Buss, London, pp 74-87

Motoike SY, Skirvin RM, Norton MA, Otterbacher AG (2001) Somatic embryogenesis and long term maintenance of embryogenic lines from fox grape. Plant Cell Tiss Org Cult 66:121-131. doi:10.1023/A:1010604628865

Murashige T, Skoog F (1962) A revised medium for rapid growth and bioassays with tobacco tissue cultures. Physiol Plant 15: 473-497. doi:10.1111/j.1399-3054.1962.tb08052.x

Navok FJ (1980) Phenotype and cytological status of plant regenerated from callus cultures of Allium sativum. Z Pflanzenzuchtg $84: 250-260$

Nonohay JS, Mariath JEA, Winge H (1999) Histological analysis of somatic embryogenesis in Brazilian cultivars of barley, Hordeum vulgare L. Poaceae. Plant Cell Rep 18:929-934. doi:10.1007/s0029 90050686

Nontaswatsri C, Fukai S (2005) Regenerative callus of Dianthus "Telstar Scarlet" showing mixoploidy produce diploid plants. Plant Cell Tiss Org Cult 83:351-355. doi:10.1007/s11240-005-6621-5

Obando M, Jordan M (2001) Regenerative responses of Cyphomandra betacea (Cav.) Sendt. (tamarillo) cultivated in vitro. Acta Horticult 560:429-432

Ochatt SJ, Patat-Ochatt EM, Moessner A (2011) Ploidy level determination within the context of in vitro breeding. Plant Cell Tiss Org Cult 104:329-341. doi:10.1007/s11240-011-9918-6

Padmanabhan K, Cantliffe DJ, Koch KE (2001) Auxin-regulated gene expression and embryogenic competence in callus cultures of sweetpotato, Ipomoea batatas (L.) Lam. Plant Cell Rep 20: 187-192. doi:10.1007/s002990000306
Park S-Y, Cho H-M, Moon H-K, Kim Y-W, Paek K-Y (2011) Genotypic variation and aging effects on the embryogenic capability of Kalopanax septemlobus. Plant Cell Tiss Organ Cult 105:265-270. doi:10.1007/s11240-010-9862-x

Pfosser M, Amon A, Lelley T, Heberle-Bors E (1995) Evaluation of sensitivity of flow cytometry in detecting aneuploidy in wheat using disomic and ditelosomic wheat-rye addition lines. Cytometry 21:387-393. doi:10.1002/cyto.990210412

Pinto G, Loureiro J, Lopes T, Santos C (2004) Analysis of the genetic stability of Eucalyptus globulus Labill. somatic embryos by flow cytometry. Theor Appl Genet 109:580-587. doi:10.1007/s00122004-1655-3

Pringle GJ, Murray BG (1991) Karyotype diversity and nuclear DNA variation in Cyphomandra. In: Hawkes JG, Lester RN, Nee M, Estrada N (eds) Solanaceae III: taxonomy, chemistry, evolution. The Royal Botanic Gardens Kew for the Linnean Society of London, London, pp 247-252

Pringle GJ, Murray BG (1992) Polyploidy and aneuploidy in the tamarillo, Cyphomandra betacea (Cav.) Sendt. (Solanaceae). I. Spontaneous polyploidy and features of the euploids. Plant Breed 108:132-138. doi:10.1111/j.1439-0523.1992.tb00112.x

Rees H, Jones RN (1972) The origin of the wide species variation in nuclear DNA content. In: Bourne GH, Danielli JF (eds) International review of cytology, vol 32. Academic Press Inc., New York, pp 53-92

Rose RJ, Mantiri FR, Kurdyukov S, Chen S-K, Wang X-D, Nolan KE, Sheahan MB (2010) Developmental biology of somatic embryogenesis. In: Pua EC, Davey MR (eds) Plant developmental biology-biotechnological perspectives, vol 2. Springer, Berlin, pp 3-26

Rugkhla A, Jones MGK (1998) Somatic embryogenesis and plantlet formation in Santalum album and S. spicatum. J Exp Bot 49: 563-571. doi:10.1093/jxb/49.320.563

Singh RJ (1986) Chromosomal variation in immature embryo derived calluses of barley (Hordeum vulgare L.). Theor Appl Genet 72:710-716. doi:10.1007/BF00289014

Slack JM (1976) Growing tamarillos. Agric Gaz NSW 86:2-4

Standring LS, Pringle GJ, Murray BG (1990) The control of chloroplast number in Solanum muricatum Ait. and Cyphomandra betacea (Cav.) Sendt. and its value as an indicator of polyploidy. Euphytica 47:71-77. doi:10.1007/BF00040366

Torrey JG (1967) Morphogenesis in relation to chromosomal constitution in long term plant tissue culture. Physiol Plant 20: 265-275. doi:10.1111/j.1399-3054.1967.tb07162.x

Vindel $\varnothing v$ LL, Christensen IJ, Nissen NI (1983) Standardization of highresolution flow cytometric DNA analysis by the simultaneous use of chicken and trout red blood cells as internal reference standards. Cytometry 3:328-331. doi:10.1002/cyto.990030504

von Aderkas P, Pattanavibool R, Hristoforoglu K, Ma Y (2003) Embryogenesis and genetic stability in long term megagametophyte-derived cultures of larch. Plant Cell Tiss Org Cult 75: 27-34. doi:10.1023/A:1024614209524

von Arnold S (2008) Somatic embryogenesis. In: George EF, Hall MA, de Klerk D (eds) Plant propagation by tissue culture, vol 1, 3rd edn., The backgroundSpringer, Dordrecht, pp 335-354

von Arnold S, Sabala I, Bozhkov P, Dyachok J, Filonova L (2002) Developmental pathways of somatic embryogenesis. Plant Cell Tiss Org Cult 69:233-249. doi:10.1023/A:1015673200621

Yang X, Zhang Y (2010) Regulation of somatic embryogenesis in higher plants. Critical Rev Plant Sci 29:36-57. doi:10.1080/ 07352680903436291 